\title{
Optimization of Energy Efficiency and Environmental Comfort in Broiler House
}

\author{
Moacir José Dalmina Junior ${ }^{1}$, Jair Antonio Cruz Siqueira ${ }^{1}$, Carlos Eduardo Camargo Nogueira ${ }^{1}$, \\ Samuel Nelson Melegari de Souza ${ }^{1} \&$ Luciene Kazue Tokura ${ }^{1}$ \\ ${ }^{1}$ Graduate Program in Energy Engineering in Agriculture, State University of West Paraná, Cascavel, Paraná, \\ Brazil \\ Correspondence: Luciene Kazue Tokura, Graduate Program, in Energy Engineering in Agriculture, State \\ University of West Paraná (UNIOESTE), Rua Universitária, 2069-Jardim Universitário, CEP: 85819-110, \\ Cascavel, Paraná, Brazil. Tel: 55-(45)-3220-3151. E-mail: lucienetokura@gmail.com
}

Received: July 1, $2020 \quad$ Accepted: August 8, $2020 \quad$ Online Published: September 15, 2020

doi:10.5539/jas.v12n10p162 URL: https://doi.org/10.5539/jas.v12n10p162

\begin{abstract}
The objective of the study was to develop a design methodology involving a mixed system for better use of natural lighting and ventilation, together with electrical heating and ventilation systems that are currently used in commercial aviaries. Two building models were analyzed, one open conventional, and the other developed specifically for this study, with a cross ventilation brise-soleil system that provided greater energy efficiency in aviaries. Subsequently, the two models were compared using Autodesk's Revit software through the Green Building Studio, to analyze the energy consumption of buildings during the year. The results showed that the model of poultry developed for the study proved to be more efficient in relation to the model of open poultry. The proposed broiler house was $21.07 \%$ more efficient than the conventional open aviary.
\end{abstract}

Keywords: thermal comfort, lighting, solar radiation, natural ventilation

\section{Introduction}

Birds are homeothermal animals, keeping the internal temperature constant, thus having a continuous change of temperature with the environment. Thus, birds need a thermal comfort zone, in which the temperature, winds and relative humidity of the air must be within the appropriate levels of comfort for the animal (Jones et al., 2005; Souza, 2005; V. M. N. Abreu \& P. G. Abreu, 2011).

According to Belay and Teeter (1993) when the temperature and relative humidity of the air surpass the recommended levels for the proper development of broilers, there will be implications for the heat exchange of the broilers, thus impairing the development of broilers during the period accommodation.

Aradas (2001), and Cravo et al. (2009), define that the thermal comfort of the aviaries is extremely important, since severe temperature conditions affect the production of the birds, reflecting in the loss of productivity.

Considering that poultry activity is one of the main sectors of animal source of protein, mainly in the southern region of the country, it is important to take into account the planning of the facilities, mainly in relation to the thermal comfort that are often carried out by energy operated equipments that demand high energy consumption. The optimization of energy in poultry has generated discussions and several studies that mention the importance of poultry farmers to identify ways to optimize the use of energy efficiency due to the high cost of electricity (Nonis \& Samed, 2014).

During the process of fattening and growth, birds must be provided proper temperature lighting (Olanrewaju et al., 2006; Kristensen et al., 2007; Lewis et al., 2007; Castellini et al., 2012; Deep et al., 2012; González-Garcia et al., 2014) and ventilation. According to Bianchi (2016) reported that the wind speed and the average radiant temperature are fundamental to determine the thermal comfort of the chicken. Fans and other equipment that require energy are currently used to maintain the best possible ambience in the aviary.

Broiler house must be designed and built to meet the environmental conditions required by birds (Seo et al., 2009; Cardoso et al., 2011). 
Thus, the search is on for new technologies to adopt in poultry facilities to achieve greater productivity at lower costs, considering the welfare of animals is necessary. One of these technologies is the use of Autodesk's Revit computer system by the Green Building Studio, which allows to virtually model the broiler house, including enough data to determine the viability of the broiler house.

The study was analyzed using Autodesk's Revit computer system by the Green Building Studio. This system compared the model developed with the conventional open-sided model. The models were tested to obtain a design methodology more adapted to the region's climate. The proposal of solar blocker and natural ventilation have the possibility to preserve and improve the thermal comfort of the birds, improving the quality of life of the animals and decreasing the expenditure of electric energy and consequently reducing the cost of production.

Given the above, the objective of the work was to develop a design methodology that would present energy efficiency in broiler houses with reduction in production costs, taking advantage of natural lighting and ventilation for better thermal comfort, adapting to the external climate, taking advantage of or blocking natural resources for the best possible ambience in the internal space of the environment.

\section{Material and Methods}

The work methodology was developed in the city of Cascavel/Paraná, located in the western region of the state, as it is one of the largest poultry producers in the region.

Project types were evaluated in order to obtain an architectural model with greater use of lighting. A brise-soleil system with the function of blocking solar radiation and a natural cross ventilation system were used, in addition to providing greater energy efficiency in broiler house.

The evaluation methods were performed by the Autodesk Revit computer system, using which the architectural model was developed and through the Green Building Studio system, energy efficiency analysis was developed. Through these computer programs, data, and variables such as temperature and heat transfer, wind flows and energy consumption were generated, along with other data.

Two building models were analyzed, one open conventional, and the other developed specifically for this study, with a cross ventilation brise-soleil system. Both models have the same electrical equipment, such as lamps and fans, with changes only in the construction and architectural elements of broiler house (open conventional broiler house and broiler house with brise-soleil system and chimney effect).

Under the same weather conditions, the analyzes were determined on the database at the weather station, located at latitude $24^{\circ} 93^{\prime} 17^{\prime \prime}$ and longitude $53^{\circ} 46^{\prime} 59^{\prime \prime}$ and altitude of $592 \mathrm{~m}$ to evaluate the performance of each model and its efficiency due to architectural qualities.

\subsection{Ventilation and External Temperature Analysis of the Broiler House}

For the analysis of the parameters, graphs were plotted for ventilation and temperatures were used. The analyzed models were evaluated for a period of one year. The annual wind frequency, the annual temperature range, the monthly temperature data, and the annual humidity data were measured.

The solar chart of the municipality of Cascavel/Paraná was performed by the Analysis Sol-AR 6.2 software (LabEEE/UFSC, 2009) (Figure 1), in which the solar incidence, the solar angle and its interference from heat and direct light can be observed. 


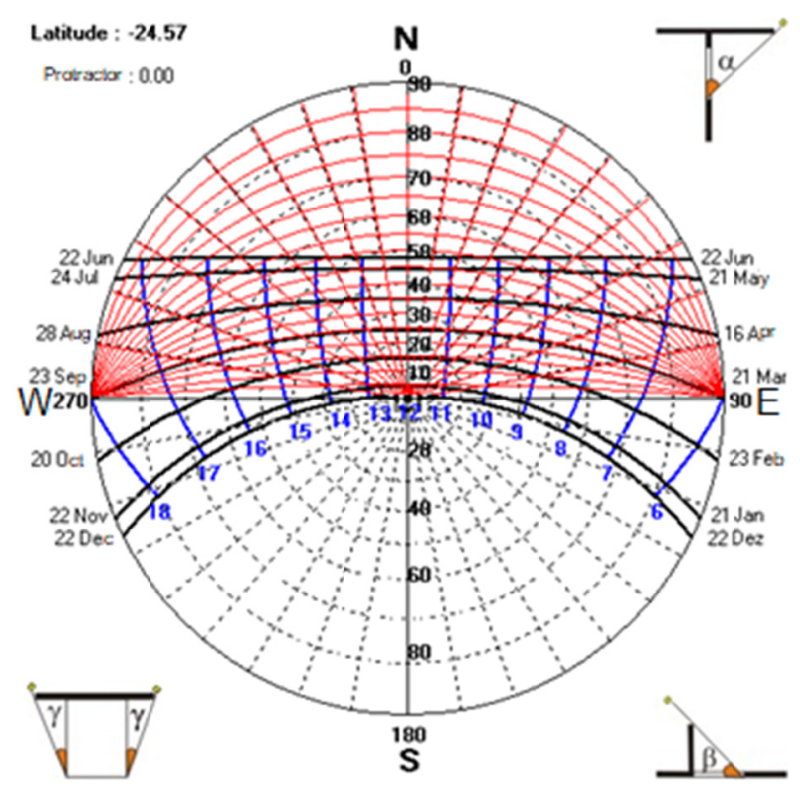

Figure 1. Cascavel solar chart, latitude $24^{\circ} 57^{\prime} 21^{\prime \prime}$ south

Source: LabEEE/UFSC (2009).

The wind rose was determined with the data collected by the weather station located at the aviary's installation site, using the Green Building Studio software (Figure 2). This Figure shows the average wind speed in the city of Cascavel and that the northeast wind is predominantly, with some fluctuations during the year. Next, the wind speed averages and their predominant directions during the seasons were determined, to observe the interference in the ventilation flows.

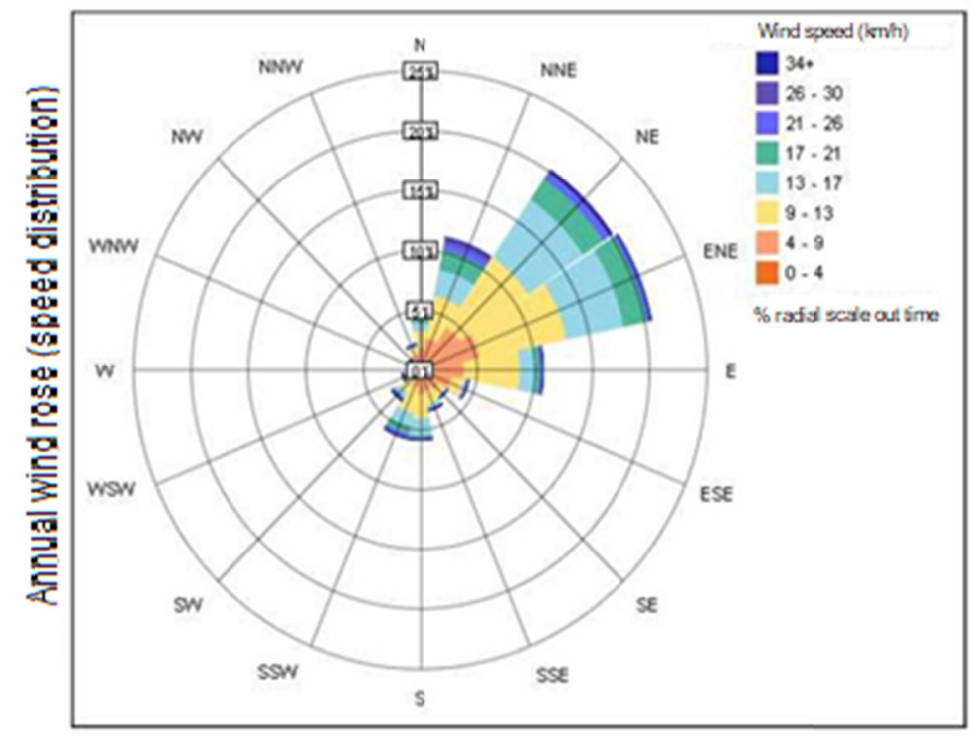

Figure 2. Wind velocity and wind direction

\subsection{Energy Consumption Analysis}

For the analysis of energy consumption, data on the use and cost of the $\mathrm{kWh} / \mathrm{year}$ of the two models were measured. The energy consumption for the use of the equipment to maintain thermal comfort in broiler house, the monthly heating load, as well as the monthly cooling load, the monthly electricity consumption, and the peak monthly demand were also recorded. All model data and graphics were prepared using the Green Building Studio software. 


\subsection{Broiler Houses Models}

For the analysis of solar incidence, two broiler houses system models were evaluated, one with conventional open cut, and the other with a system with adjustable openings with brise-soleil and cross ventilation with chimney effect (study proposal). The fans and lamps arrangements were the same in both models.

According to Bianchi (2016), the heat generation of the chickens is relatively complex, increasing with the growth of the chicken and varying throughout the day.

As the objective of this work was to evaluate, most efficient architectural model, all the elements for control of internal environment were the same in both models except changes in construction.

\subsubsection{Open Conventional Broiler House}

The open conventional broiler house was based on the model sold the market, its construction part being made of wood and masonry structure, with the closures with canvas and cover with $6 \mathrm{~mm}$ fiber cement tile (Figure 3 ).

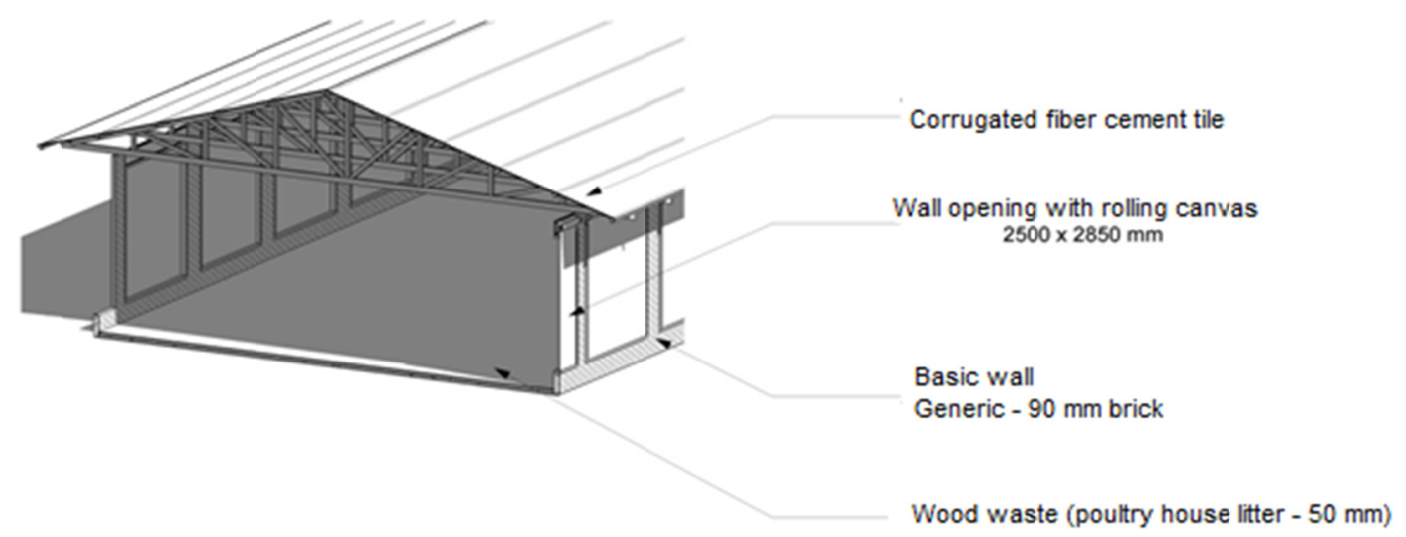

Figure 3. Open conventional broiler house

According to Bedin (2015) in implementation of projects for poultry building, the location, orientation, dimensioning, roof, shading, and external afforestation must be carefully observed, in addition to the climatic elements. Otherwise, it may generate a situation of thermal discomfort, especially during the hot seasons of the year, with loss of bird productivity.

\subsubsection{Broiler House With Brise-Soleil System and Chimney Effect}

The brise-soleil system device was installed horizontally, on the north facade of the aviary, which will block the face with the greatest solar incidence during hot days, but allow the entry of light (Figure 4).

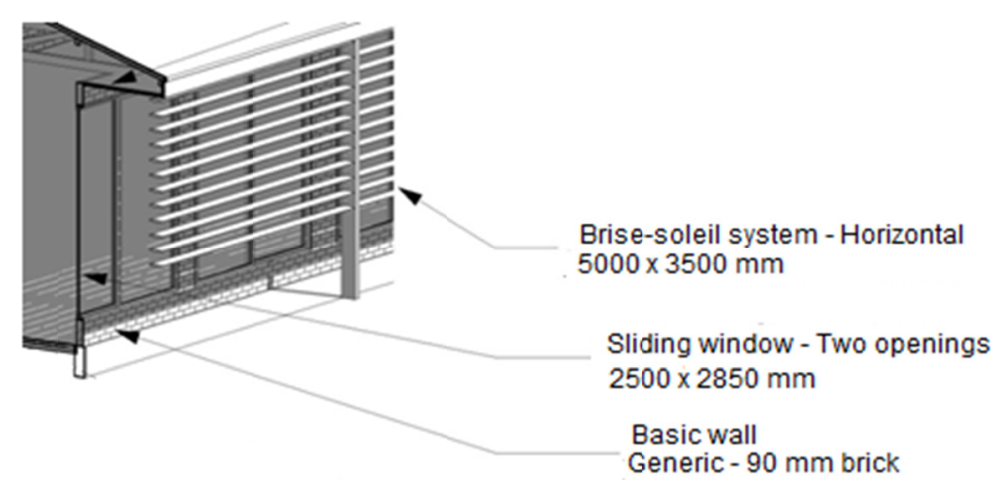

Figure 4. Arrangement of brise-soleil system in the aviary

The ventilation system was cross ventilated with a chimney effect. According to Mascaró (1991), this system is mainly effective in cooling surfaces by convection, especially in hot periods of humid climates. This system 
provides greater exchange of indoor air with the outside, so the more frequent the exchange, the greater the comfort of the indoor environment (Figure 5).

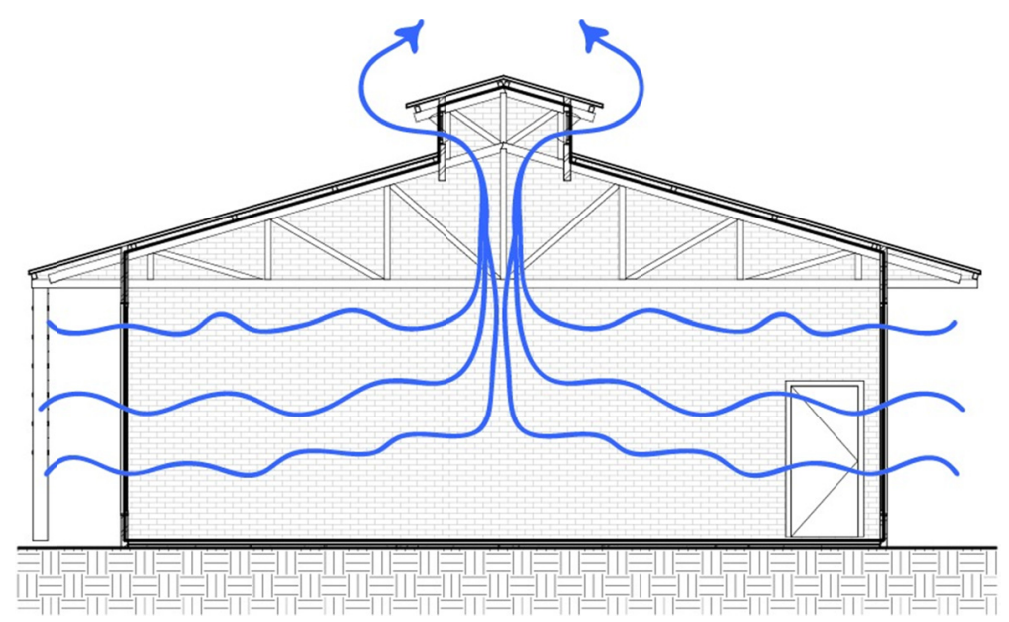

Figure 5. Cross ventilation system and chimney effect

In this system, it is possible to optimize natural ventilation and removal of hot air, to keep internal air continually renewed controlling the temperature as close as possible to the desirable one.

According to Hertz (2003) the most important aspect of this technique is its ability to decrease the temperature of the structure, that is, to lower the temperature of the architectural elements that form the environment in order to provide thermo comfort zone.

This system has been designed considering cold and hot days, regulating the internal temperature to provide greater comfort to the birds. In addition it reduces the need for heating and cooling systems that demand electricity, reducing consumption and optimizing production.

The brise-soleil system was fixed on the north façade where the solar incidence is greater, in order to decrease the internal temperature and reduce energy consumption. There is also the replacement of the roof by a thermo acoustic tile made of Styrofoam coated in steel, reducing the thermal conduction of the roof and minimizing the use of equipment that requires consumption of electricity to regulate the temperature of the environment. A system for capturing air through opposite openings that directly affects the interior of the environment, and a top opening for the chimney effect that performs the exchange of air, removing the hot air from the environment, mainly through the conduction of the roof heating and providing greater thermal comfort and reducing the conduction of solar radiation into the environment.

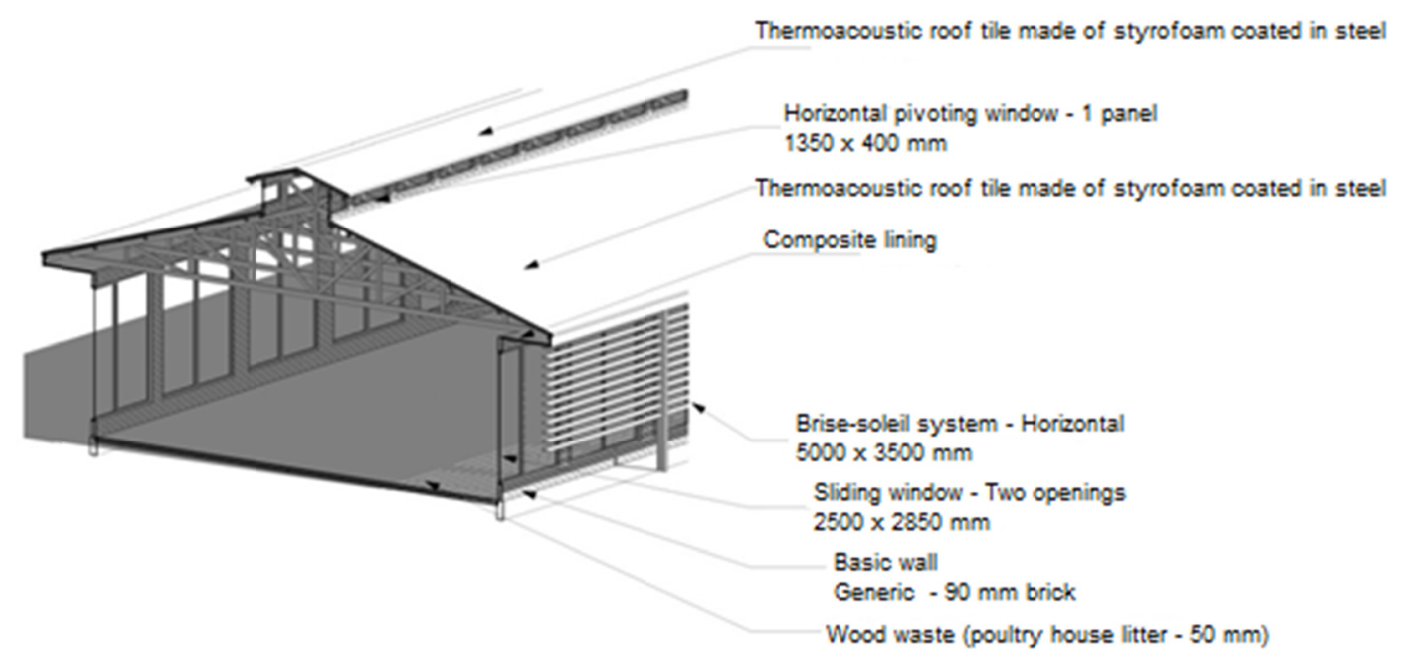

Figure 6. The brise-soleil system 
According to Hertz (2003) negative pressures force the hot air to rise by convection, producing a drop in internal pressure. Thus, the lowest temperature outdoor air enters the environment, while the warmest indoor air escapes through the ceiling.

The model developed for the study presented some specific changes to improve the environmental comfort of the aviary to reduce radiation and improve ventilation to change the indoor air of the building more efficiently.

\section{Results and Discussion}

Results of the comparison of the proposed model with the open conventional broiler house, processed by the Green Building Studio software with analysis of the building for one year.

\subsection{Incidence of Ventilation and External Temperatures of the Broiler House}

The ventilation and temperature data are the same for the two broiler houses, since they were carried out by the same weather station, thus the annual distribution of wind frequencies (Figure 7) and temperatures were the same in both models.

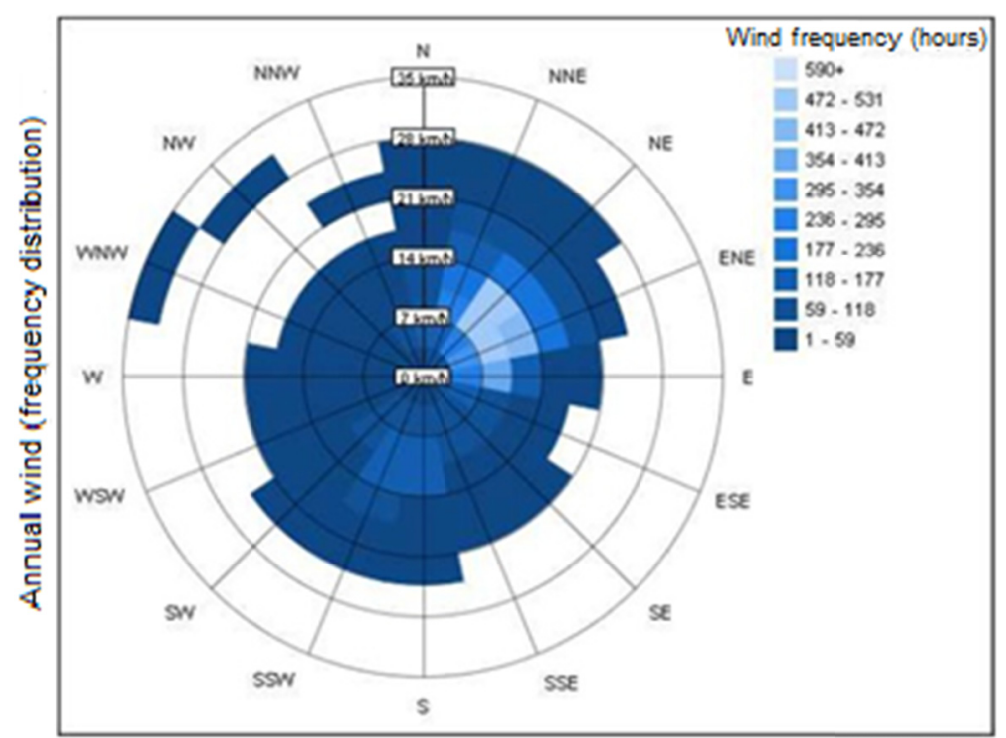

Figure 7. Annual wind frequency distribution

The wet bulb temperature was lower due to the heat used to evaporate the water, and its cooling was due to the dry air, so the drier the air, the greater the cooling. The greater the difference in temperature between them, the lower the relative humidity of the air, thus, the smaller the difference the greater the relative humidity of the air (Grimm, 1999).

In Figure 8, the wet bulb and dry bulb relationship can be observed, in the temperature ranges in relation to the amount of time in annual hours that the broiler house was exposed. 


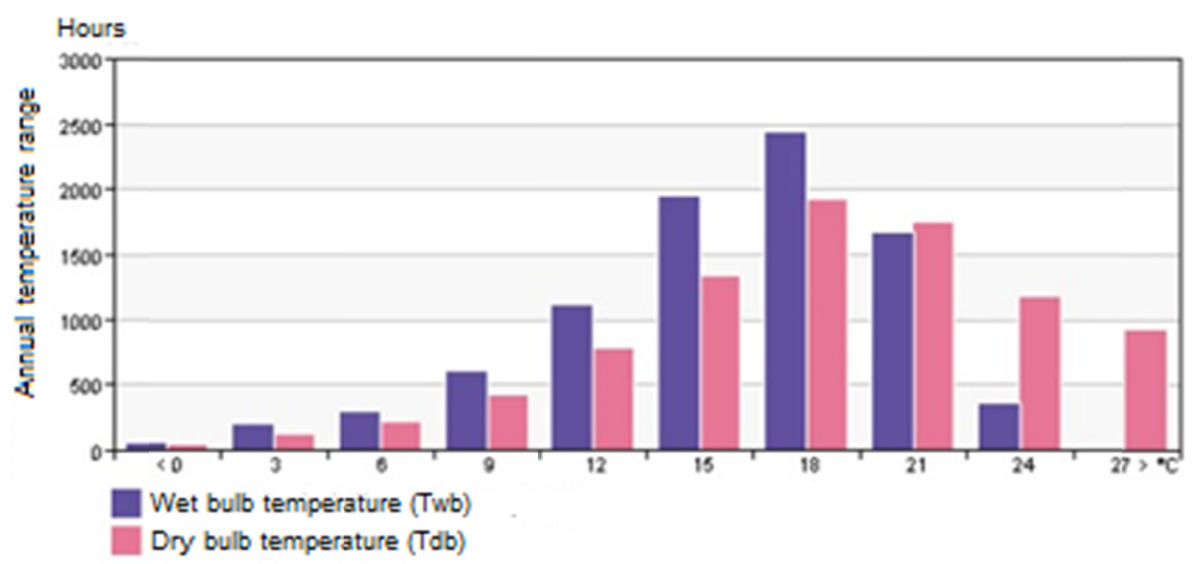

Figure 8. Annual dry bulb and wet bulb temperature range

Figure 9 shows the monthly data of the minimum and maximum monthly average of the dry bulb temperature range for cooling and heating, as well as the average dry bulb range for each month of the year. The highest levels are found in the spring and summer seasons, which are the hottest months of the year, and the lowest levels in winter and autumn, which are the coldest months of the year.

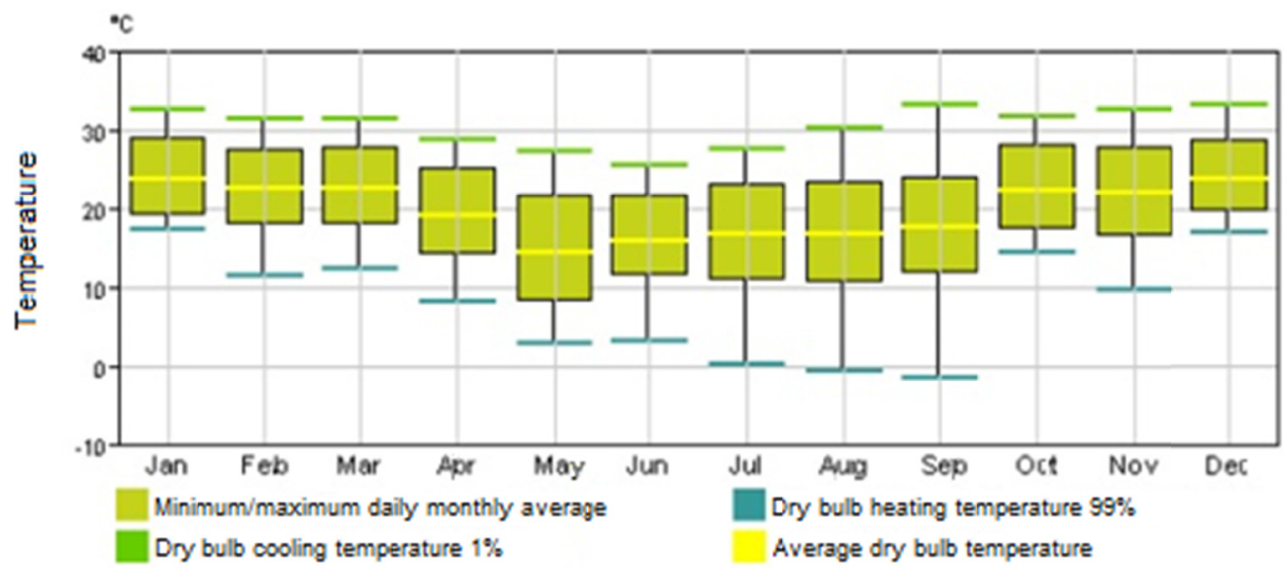

Figure 9. Average, minimum and maximum monthly temperature of cooling and heating dry bulb in both aviaries

The relative humidity of the air (UR\%) indicates saturation than actual amount of water vapor in the air (GRIMM, 1999).

In Figure 10, monthly humidity levels and morning and afternoon averages can be seen at the location of the broiler house. 


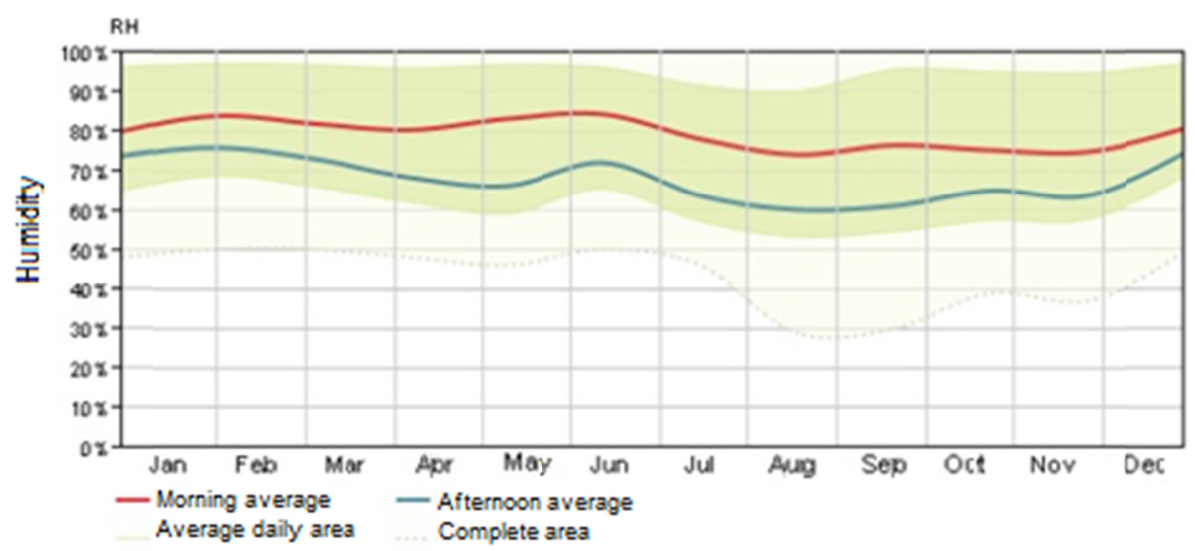

Figure 10. Monthly humidity with morning and afternoon averages

\subsection{Energy Consumption and Thermal Comfort of Broiler Poultry Houses}

The equipment, the number of chickens and the heat generation were the same in both models, except for the architectural elements of broiler house. Figures 11 and 12 show the energy consumption of the aviaries during the period of one year.

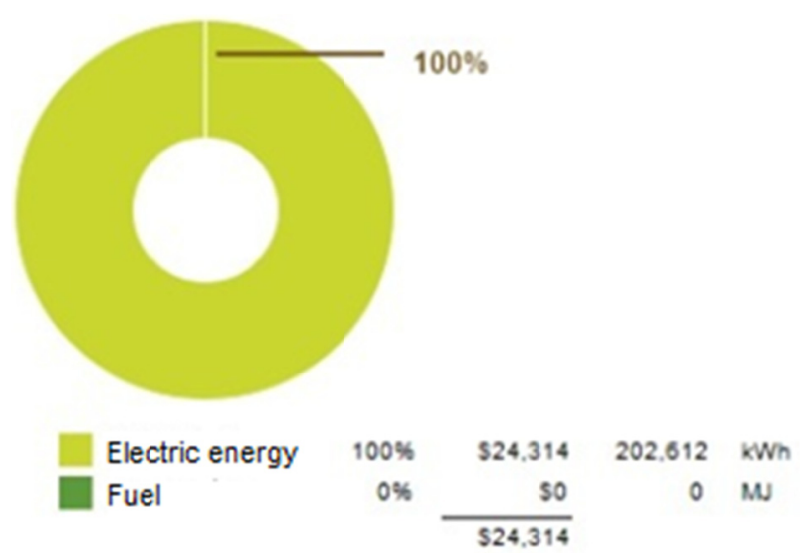

Figure 11. Electric energy consumption and annual electric energy cost in the open broilers house

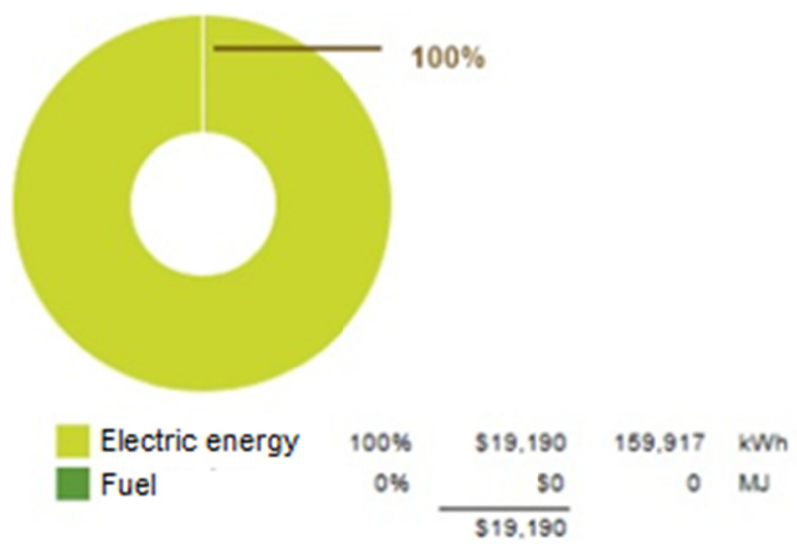

Figure 12. Electric energy consumption and annual electric energy cost in the architecturally modified broiler house

Electric energy consumption in the two broiler houses is shown in Figures 13 and 14. 
For both types of broiler houses, the heating, ventilation systems, artificial lighting system, and equipment demands electric energy.

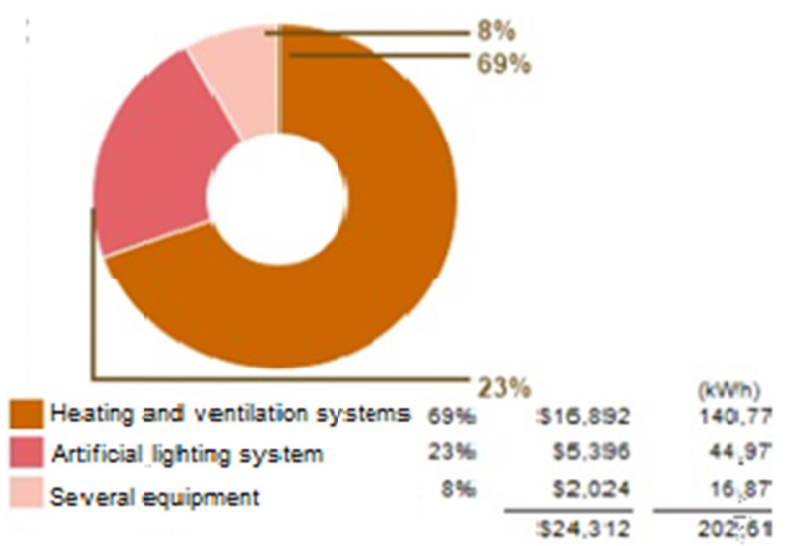

Figure 13. Electric energy demand in the open broilers house

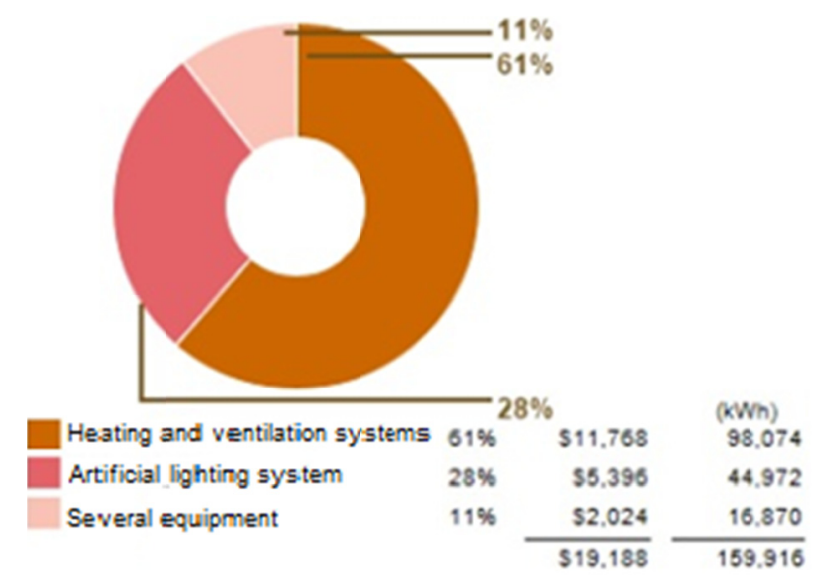

Figure 14. Electric energy demand in the model broiler house developed for the study

The monthly electric energy demand for heating the internal environment, as well as the broiler house heat gain and loss factors, through materials, equipment or broiler house openings can be seen in Figures 15 and 16.

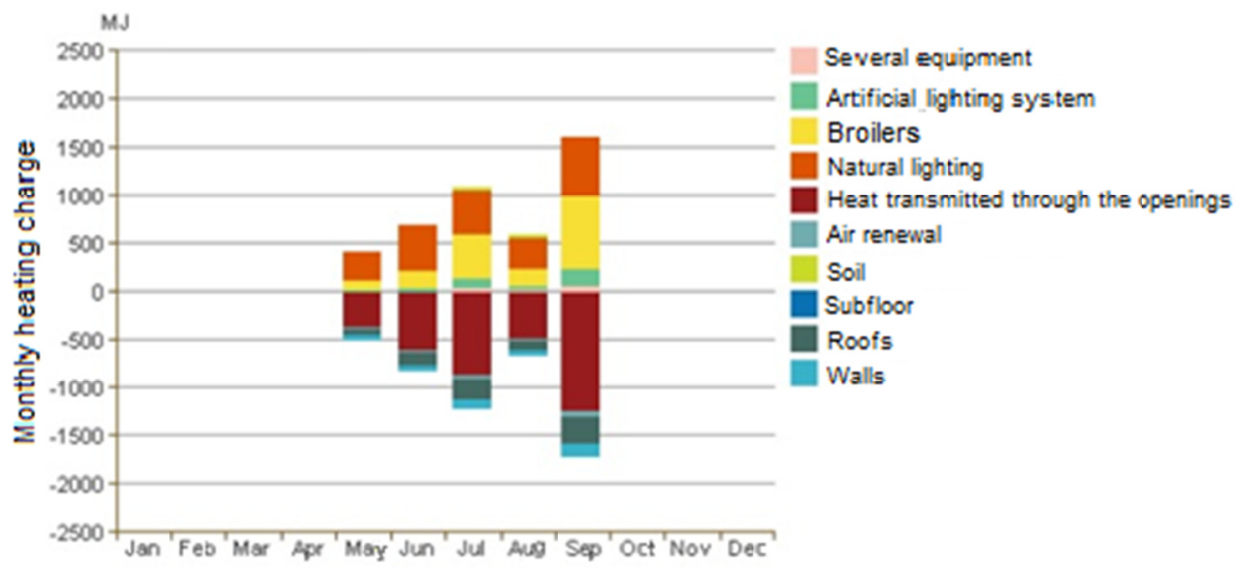

Figure 15. Monthly heating load in the open broilers house 


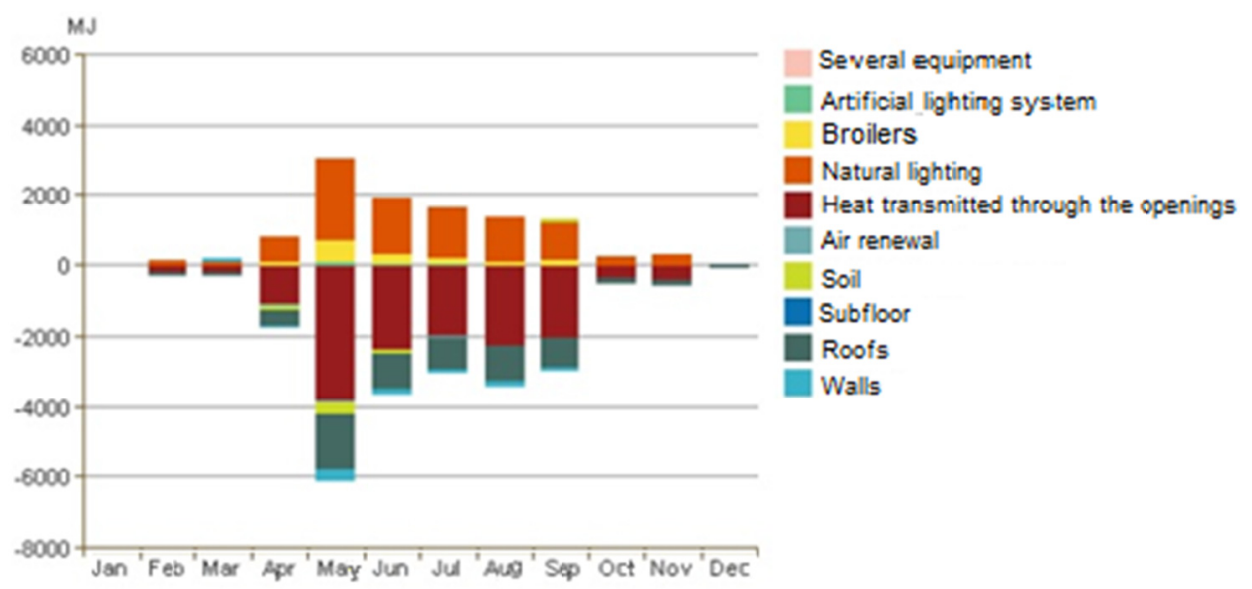

Figure 16. Monthly heating load in the broiler house developed for the study

Figures 17 and 18 show the monthly electric energy demand for cooling the internal environment, and the elements that require greater electric energy consumption to regulate the thermal comfort of the environment.

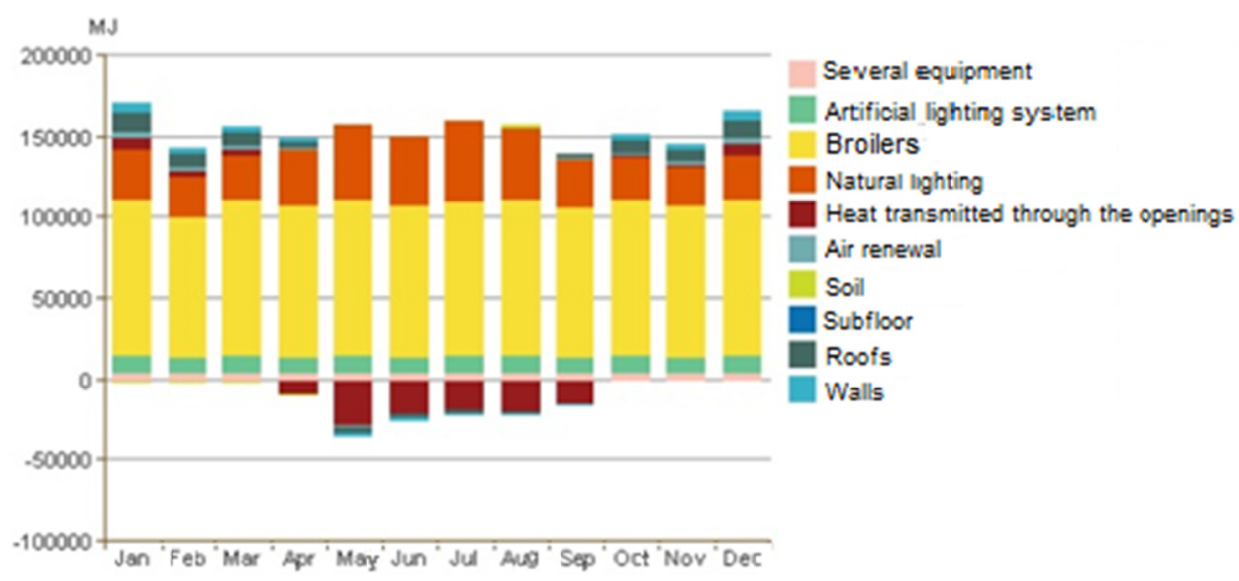

Figure 17. Monthly refrigeration load in the open broilers house

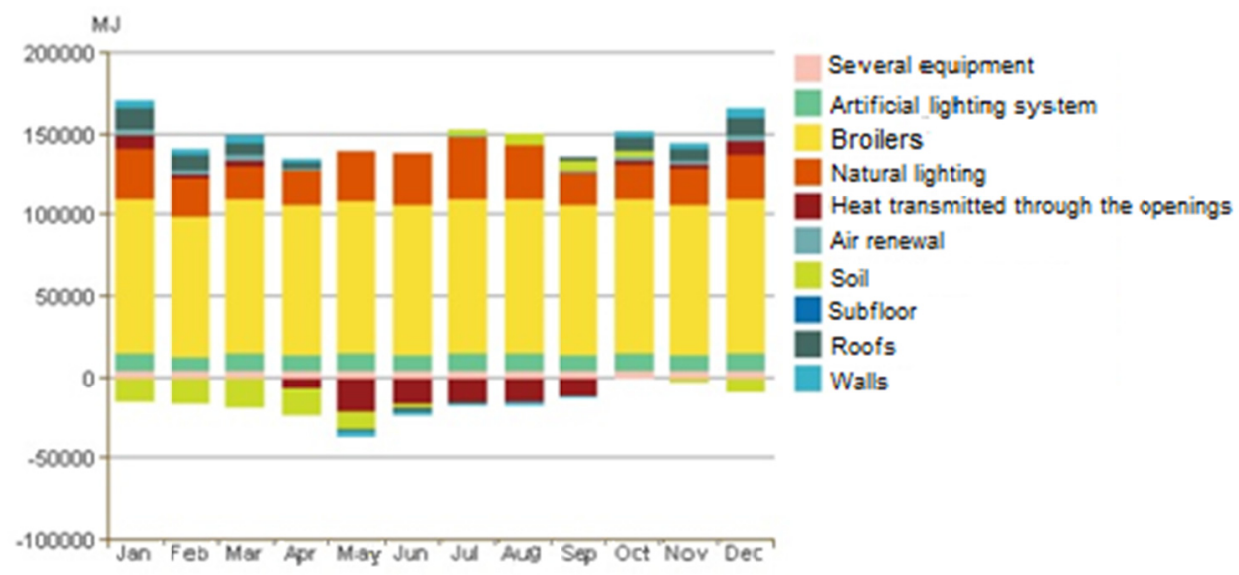

Figure 18. Monthly refrigeration load in the broiler house developed for the study

Figures 19 and 20 show the monthly electric energy consumption. 


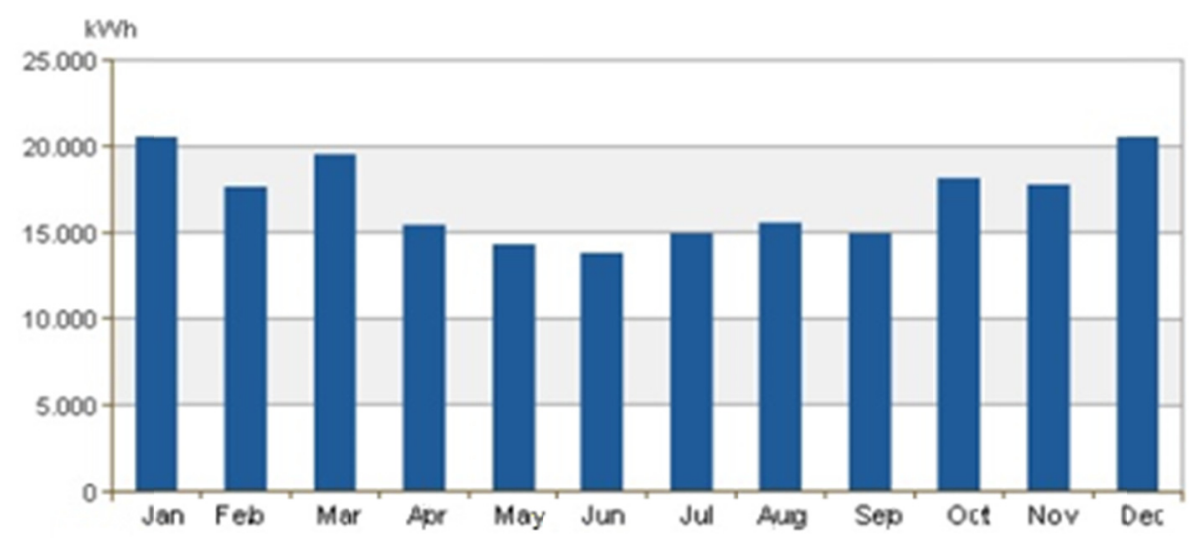

Simulated electrical energy ( $\mathrm{kWh})$

Figure 19. Monthly electric energy consumption in the open broilers house

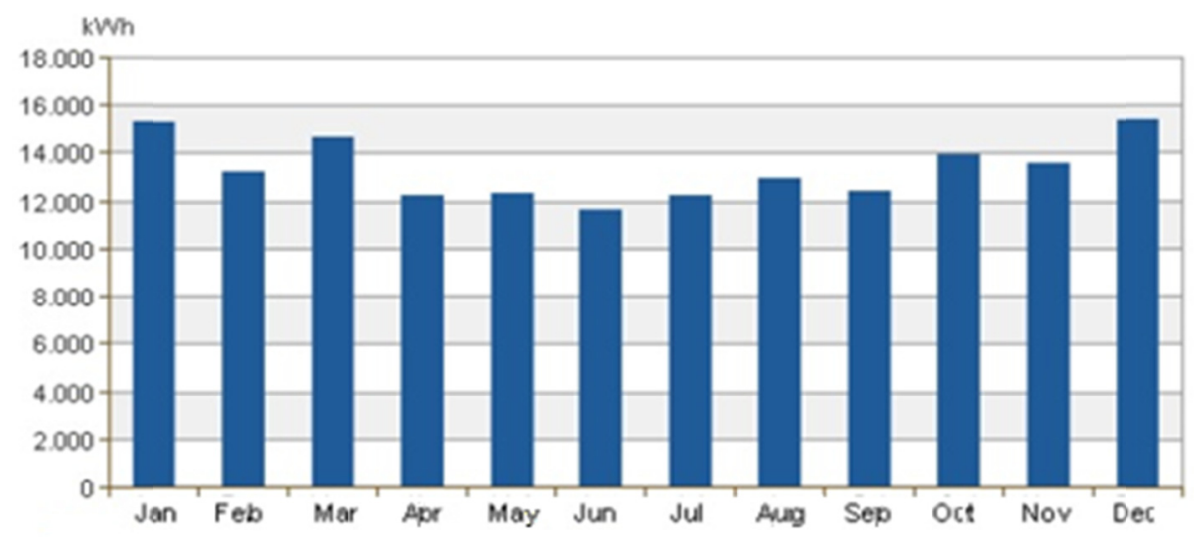

Simulated electrical energy (kWh)

Figure 20. Monthly electric energy consumption in the broiler house developed for the study

The broiler house studied showed greater efficiency in the monthly consumption of electric energy compared to the conventional open aviary.

Figures 21 and 22 show the monthly demand for electric energy peaks.

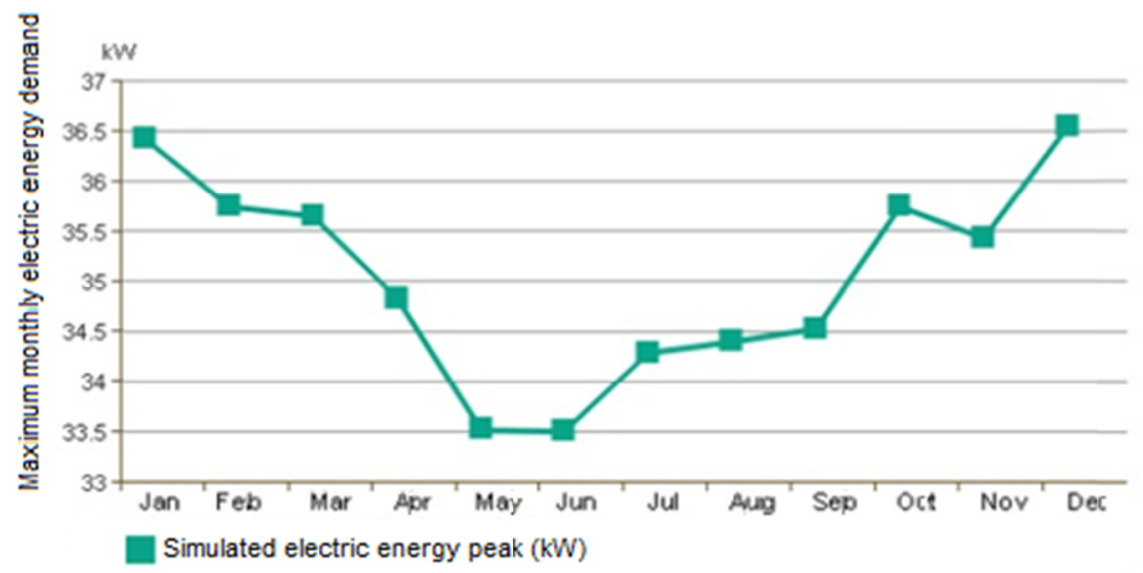

Figure 21. Monthly demand at peak electric energy levels in the open broiler house 


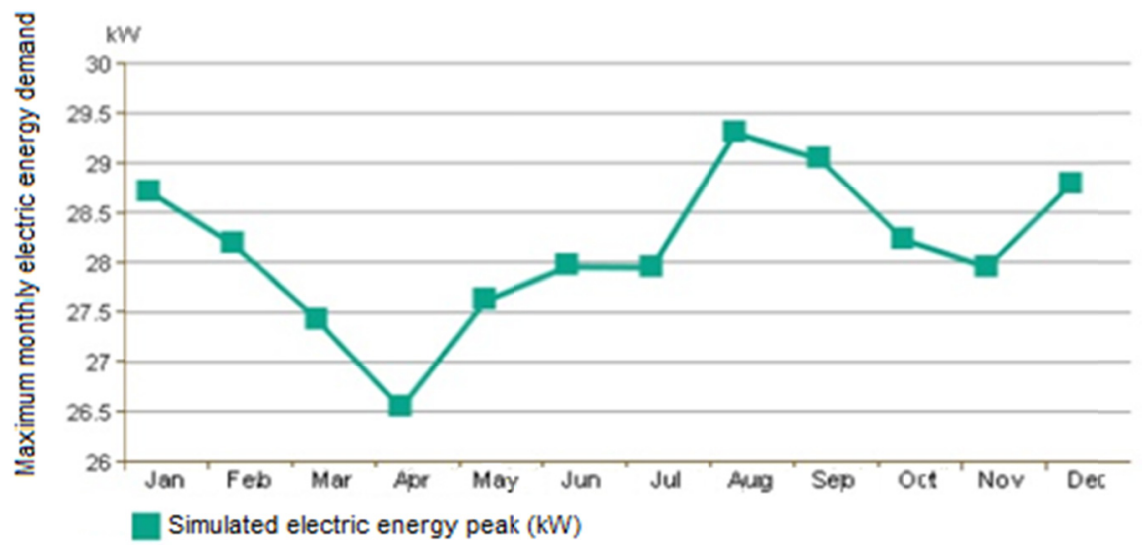

Figure 22. Monthly demand for electric energy power surges in the broiler house developed for the study

Again, the proposed broiler house presented greater efficiency in the monthly demand in the peaks of electric energy in relation to the conventional model.

The proposed model was $21.07 \%$ more efficient than the conventional open model, thus evidencing the importance of studies and new project methodologies. This result is mainly due to the use of brise-soleil system on the north facade, blocking solar radiation, and through the chimney effect, minimizing the heat transmission through the roof, being one of the main factors of thermal conduction. According to Lamberts, Dutra, and Pereira (2004), with the energy crisis and discussions of environmental impacts worldwide, there is a need for the search for new architectural proposals closer to available technologies and with a focus on environmental preservation.

\section{Conclusions}

There was blockade of solar radiation and thermal reduction inside the broiler house with the use of the solar blocking brise-soleil system.

The ventilation of the broiler house proposed by the study was more efficient, due to the chimney effect.

The proposed broiler house was $21.07 \%$ more efficient than the conventional open aviary.

\section{References}

Abreu, V. M. N., \& Abreu, P. G. (2011). The challenges of animal environment on the poultry systems in Brazil. Revista Brasileira de Zootecnia, 40(2), 1-14. Retrieved from https://www.alice.cnptia.embrapa.br/bitstream/ doc/901939/1/osdesafiosdaambienciasobreossistemas.pdf

Aradas, M. E. C. (2001). Avaliação do controle do ambiente em galpões de frangos de corte criados em alta densidade (Tese (Doutorado), Faculdade de Engenharia Agrícola, UNICAMP, Campinas).

Bedin, J. (2015). Avaliação do consumo energético em aviários dark house, com e sem isolamento térmico: Um estudo de caso na região de Palotina. Paraná. Cascavel: UNIOESTE.

Belay, T., \& Teeter, R. G. (1993). Broiler water balance and thermobalance during thermoneutral and high ambient temperature exposure. Poultry Science, 72(1), 116-124. https://doi.org/10.3382/ps.0720116

Bianchi, M. V. A. (2016). Velocidade do ar e isolamento térmico de galpões de frango de corte não são independentes. Avicultura Industrial. Retrieved from https://www.aviculturaindustrial.com.br/imprensa/ velocidade-do-ar-e-isolamento-termico-de-galpoes-de-frango-de-corte-nao-sao/20131127-083322-Z494

Cardoso, A. S., Baeta, F. C., Tinôco, I. F. F., \& Cardoso, V. A. S. (2011). Alternative cover materials for animal production sheds for thermal confort. Engenharia na Agricultura, 19(5), 404-442. https://doi.org/10.13083/ reveng.v19i5.261

Castellini, C., Boggia, A., Crtina, C., Dal Bosco, A., Paolotti, L., Novelli, E., \& Mugnai, C. (2012). A multicriteria approach for measuring the sustainability of different poultry production systems. Journal of Cleaner Production, 37, 192-201. https://doi.org/10.1016/j.jclepro.2012.07.006

Cravo, J. C. M., Fiorelli, J., Lahr, F. A. R., Fonseca, R., \& Cruz, V. C. (2009). Evaluation of recycled tiles and osb ceiling materials in closed broiler house prototypes. Brazilian Journal of Poultry Science, 11(4), 219-224. https://doi.org/10.1590/S1516-635X2009000400002

Deep, A., Schwean-Laedner, K., Crowe, T. G., Fancher, B. I., \& Classen, H. L. (2012). Effect of light intensity 
on broiler behaviour and diurnal rhythms. Applied Animal Behaviour Science, 136(1-15), 50-56. https://doi.org/10.1016/j.applanim.2011.11.002

González-Garcia, S., Gomez-Fernández, Z., Dias, A.C., Feijoo, G., Moreira, M. T., \& Arroja, L. (2014). Life cycle assessment of broiler chicken production: a Portuguese case study. Journal of Cleaner Production, 74(1), 125-134. https://doi.org/10.1016/j.jclepro.2014.03.067

Grimm, A. M. (1999). Meteorologia Básica-Notas de aula: Prof. Alice Marlene Grimm. Primeira versão eletrônica-setembro 1999. Departamento de física UFPR, Disciplina Básica da Universidade Federal do Paraná. Retrieved from http://fisica.ufpr.br/grimm/aposmeteo/cap5/cap5-5.html

Hertz, J. (2003). Ecotécnicas em Arquitetura: Como projetar nos trópicos úmidos do Brasil. São Paulo: Pioneira Thomson Learning.

Jones, T. A., Donnelly, C. A., \& Stamp Dawkins, M. (2005). Environmental and management factors affecting the welfare of chickens on commercial farms in the United Kingdom and Denmark stocked at five densities. Poultry Science, 84, 1155-1165. https://doi.org/10.1093/ps/84.8.1155

Kristensen, H. H., Prescott, N. B., Perry, G. C., Ladewing, J., Ersboll, A. K., Overvad, K. C., \& Wathes, C. M. (2007). The behavior of broiler chickens in different light sources and illuminances. Applied Animal Behaviour Science, 103(1-2), 75-89. https://doi.org/10.1016/j.applanim.2006.04.017

LabEEE (Laboratório de Eficiência Energética em Edificações). (2009). Homepage do laboratório de pesquisa. Florianópolis: Universidade Federal de Santa Catarina. Retrieved from http://www.labeee.ufsc.br/ downloads/softwares/analysis-sol-ar

Lamberts, R., Dutra, L., \& Pereira, F. O. R. (2014). Eficiência Energética na Arquitetura (3rd ed.). São Paulo: Editora ELETROBRAS/PROCEL.

Lewis, P. D., Ghebremariam, W., \& Gous, R. M. (2007). Illuminance and UV-A exposure during rearing affects egg production in broiler breeders transferred to open-sided adult housing. British Poultry Science, 48(4), 424-429. https://doi.org/10.1080/00071660701543105

Mascaró, R. L. (1991). Energia na edificação: Estratégia para minimizar o consumo. São Paulo: Projeto Editores Associados LTDA.

Olanrewaju, H. A. J. P., Thaxton, W. A., Dozier I. J., Purswell, J., Roush, W. B., \& Branton, S. L. (2006). A review of lighting programs for broiler production. International Journal of Poultry Science, 5(4), 301-308. https://doi.org/10.3923/ijps.2006.301.308

Seo, I. H., Lee, I. B., Moon, O.-K., Kim, H.-T., Hang, H.-S., Hong, S.-W., ... Han, J.-W. (2009). Improvement of the ventilation system of a naturally ventilated broiler house in the cold season using computational simulations. Biosystems Engineering, 104(1), 106-117. https://doi.org/10.1016/j.biosystemseng.2009.05.007

Souza, P. (2005). Avicultura e clima quente: Como administrar o bem-estar às aves? Revista Avicultura Industrial, 96(4), 52-58. Retrieved from http://www.refresque.com.br/Downloads/Avicultura-Clima-Quente_Artigo.pdf

\section{Copyrights}

Copyright for this article is retained by the author(s), with first publication rights granted to the journal.

This is an open-access article distributed under the terms and conditions of the Creative Commons Attribution license (http://creativecommons.org/licenses/by/4.0/). 